\title{
COMPARISON OF THE DEFLUORIDATION CAPACITY OF ZEOLITES FROM ETHIOPIA AND MEXICO
}

\author{
Mohammedali Adem ${ }^{1}$, Taju Sani ${ }^{1}$, Yonas Chebude ${ }^{1}$, Geolar Fetter ${ }^{2}$, Pedro Bosch ${ }^{1,3}$ and \\ Isabel Diaz ${ }^{1,4, *}$ \\ ${ }^{1}$ Chemistry Department, Addis Ababa University, P. O. Box 1176, Addis Ababa, Ethiopia \\ ${ }^{2}$ Benemérita Universidad Autónoma de Puebla, Puebla, Mexico \\ ${ }^{3}$ Instituto de Investigaciones en Materiales, Universidad Nacional Autónoma de México, \\ Mexico \\ ${ }^{4}$ Instituto de Catálisis y Petroleoquímica, CSIC, c/Marie Curie 2, 28049 Madrid, Spain
}

(Received April 28, 2014; revised October 23, 2014)

\begin{abstract}
Fluorosis, either dental or skeleton, is often due to the high fluoride content of well waters. In this work, using solutions which contain different amounts of fluoride, natural zeolites from Ethiopia and Mexico were tested. It is shown that, although zeolites are known to be cationic exchangers, their extra-framework aluminum and their high calcium contents determine their performance. A mechanism involving adsorption and ion exchange is proposed.
\end{abstract}

KEY WORDS: Ion exchange, Purification, Fluorosis, Clinoptilolite, Stilbite, Heulandite, Analcime

\section{INTRODUCTION}

Fluorine is a halogen non-metal, it is the $24^{\text {th }}$ most abundant element in the universe and the $13^{\text {th }}$ within the Earth's crust. Fluorine, being the most electronegative of all elements, is found as fluoride ion in nature. As a trace element, fluoride is essential for strengthening the bones and preventing dental cavities, it is especially beneficial to young children below eight years of age; however, an excess intake is detrimental to human health.

Excess ingestion of fluoride can cause dental/skeleton fluorosis [1]. It does not only affect teeth and skeleton but its accumulation over a long period of time can lead to cancer, osteosclerosis and it has been also related with neurological impairment in human beings [2]. On the one hand, fluoride pollution of water occurs either through natural processes or through human activities. Indeed, fluoride is often present in minerals and with rainwater erosion it can leach out, polluting ground and surface water. On the other hand, fluoride contamination occurs in a wide range of industrial wastewaters produced from aluminum and steel production as well as electroplating, glass and semiconductor manufacturing, ore beneficiation, or fertilizer uses [3]. According to WHO guidelines, the acceptable fluoride concentration in drinking water must be in the range 0.5 to $1.5 \mathrm{mg} \mathrm{L}^{-1}$ [4].

More than 260 million people all over the world consume drinking water with a fluoride concentration higher than $1.0 \mathrm{mg} / \mathrm{L}$. The majority of these people live in tropical regions, fourteen countries in Africa, eight in Asia, and six in the Americas [5, 6] (Figure 1). Many of them are confronted with problems due to endemic fluorosis, either dental or skeletal.

In Mexico, as well, mean fluoride concentrations in urban locations range from 1.5 to 2.8 $\mathrm{mg} \mathrm{L}^{-1}$ with concentrations as high as $7.8 \mathrm{mg} \mathrm{L}^{-1}$ in cities as Hermosillo, in Sonora State. In rural locations mean levels between 0.9 and $4.5 \mathrm{mg} \mathrm{L}^{-1}$ have been recorded; the highest recorded concentration has been $8 \mathrm{mg} \mathrm{L}^{-1}$ (Abasolo in Guanajuato State). States with high fluoride levels include Aguascalientes, Chihuahua, Coahuila, Durango, Guanajuato, San Luis Potosí and Sonora $[10,11]$, i.e. the north of the country (Figure 2).

\footnotetext{
*Corresponding author. E-mail: idiaz@icp.csic.es
} 
In Ethiopia, the ground water of the Rift Valley area (which runs from Addis Ababa to the South, in the Oromia State), used by most rural communities for drinking purpose, may reach fluoride levels ranging from 0.4 to $36 \mathrm{mg} \mathrm{L}^{-1}$ [6-8] (Figure 2). A study conducted by Haimanot et al. [8] found dental fluorosis in more than $80 \%$ of the sampled children resident in the Rift Valley $(1,221$ out of 1,456$)$.

Thus, the problem is severe and needs immediate solution. At present, a series of technologies exist to alleviate or at least to minimize the effect of fluoride problem. Since more than one hundred years [12], a large number of materials and methods have been proposed. The methods may be classified as chemical precipitation, ion exchange, adsorption, and membrane based mechanisms. However, most of them present disadvantages, which may be summarized as follows: Chemical precipitation yields low treatment efficiency, requires large dosage of aluminum sulfate, and has adverse health effects of dissolved aluminum species in the treated water. In the case of ion exchange, the presence of other anions such as sulfate, phosphate, bicarbonate, etc. results in ionic competition, it is relatively costly, and treated water sometimes has a low $\mathrm{pH}$ and high levels of chloride. Finally, membrane based mechanisms require skilled manpower, it is pricy, and it may not be suitable for water with high salinity and TDS (total dissolved solids). Instead, adsorption processes are attractive due to their effectiveness, convenience, easy availability, ease of operation, and economical as well as environmental low impact [13].

Many adsorbents have been tested for fluoride removal, including activated alumina, activated carbon and red mud $[14,15]$. Low cost methods such as adsorption on clays and other locally available materials like diatomaceous earth and bone [13] have been considered in some studies, even carbonaceous materials obtained from coffee grounds have been proposed [16]. Despite the encouraging results, these adsorbents have many disadvantages. The leaching of toxic ions into the "purified" water and their high cost are among the major barriers that prevent these adsorbents from being applicable on a large scale [15].

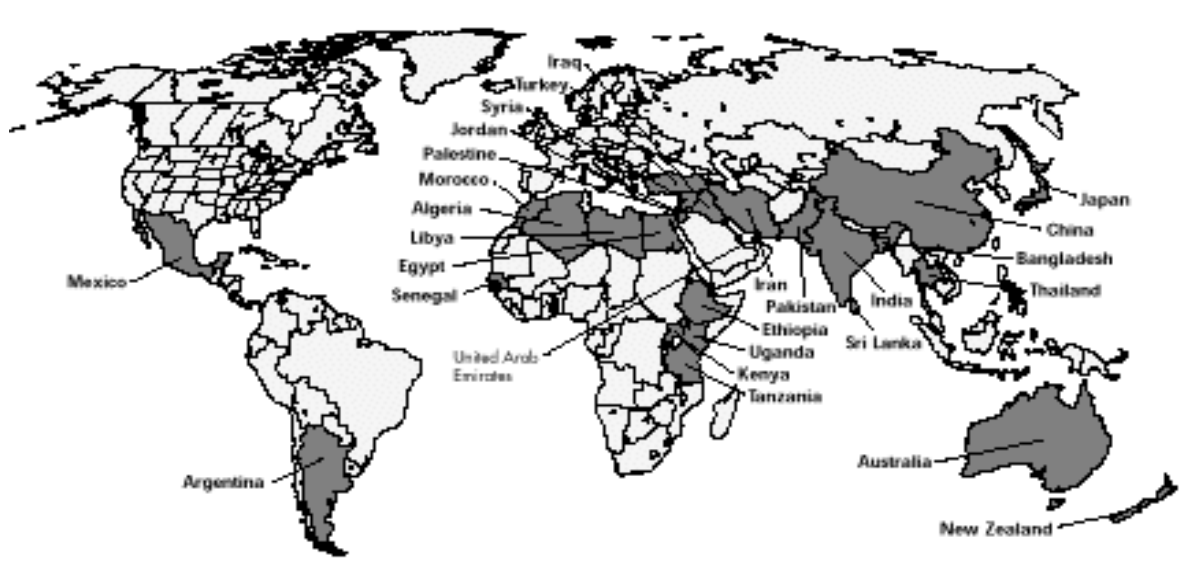

Figure 1. Map showing the endemic fluorosis areas of the world [6].

The relative cheapness, local availability and ion exchange capacity of natural zeolites make them favorable for wastewater treatment to remove unwanted ions [17, 18]. The idea lying behind the choice of zeolites is to use cheap natural minerals that may be exploited in the vicinity of the fluorosis affected area. Zeolites (clinoptilolite, stilbite and analcime) are potential candidates and thus they have been tested for fluoride removal from drinking water in Ethiopia and in Mexico [19-21]. In this work we compare the previously tested Ethiopian zeolites 
(stilbite and analcime [19]) with Mexican zeolites, namely clinoptilolite and heulandite, in order to rationalize the influence of the structure and $\mathrm{Si} / \mathrm{Al}$ ratio in the fluoride removal mechanism. Two samples have the same structure but they differ in the $\mathrm{Si} / \mathrm{Al}$ ratio (clinoptilolite and heulandite), and the other two zeolites (stilbite and analcime) differ in origin, structure, and exchangeable cations.

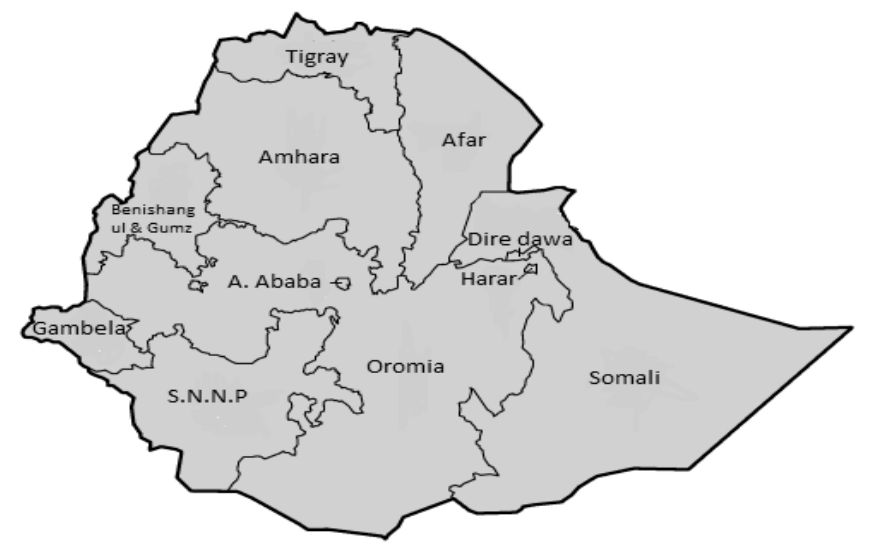

(a)

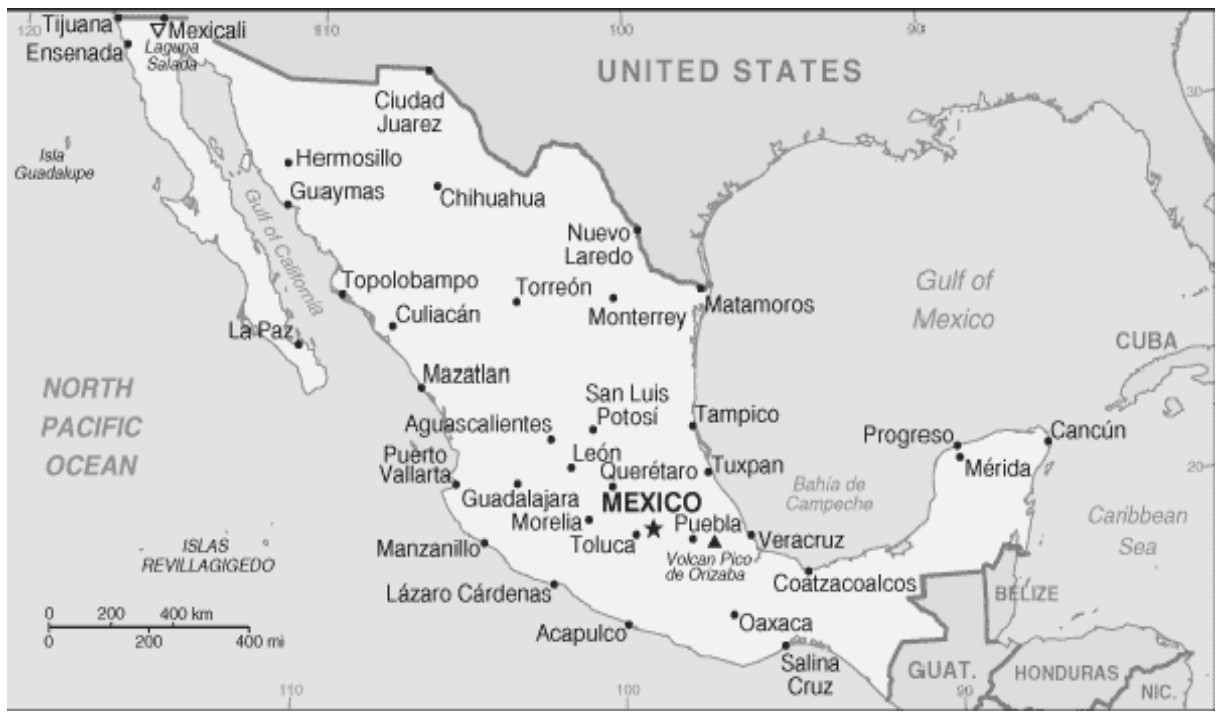

(b)

Figure 2. (a) Map showing the nine regions and two chartered cities of the Ethiopian Republic. The ground water of the Rift Valley area (in the Oromia State) has very high fluoride levels. (b) Map showing the states of the Mexican Republic. The states with elevated fluoride levels include Aguascalientes, Chihuahua, Coahuila, Durango, Guanajuato, San Luis Potosi and Sonora. 


\section{EXPERIMENTAL}

\section{Adsorbents}

A raw natural clinoptilolite, commercially labeled Zeocat ECO, was obtained from Mexico, a clinoptilolite rock from San Luis Potosí (Mexico), a heulandite (greenish) from Puebla (Mexico), and analcime and stilbite from the Hashenge basalt formation, in the locality of Hashenge, Tigray region (Ethiopia), Figure 2. All raw samples except the zeolite from Puebla (Mexico), which was obtained as the desired powder form, were crushed and sieved to the particle size fraction $75-105 \mu \mathrm{m}$ and prepared for the experiments. All other chemicals used were at least reagent grade.

\section{Reagent and standard solutions preparation}

A $0.1 \mathrm{~mol} \mathrm{~L}^{-1}$ sodium fluoride stock solution was prepared by dissolving $2.0995 \mathrm{~g}$ of anhydrous sodium fluoride $(99.0 \% \mathrm{NaF}$, SIGMA-ALDRICH, Germany) in $0.5 \mathrm{~L}$ volumetric flask with deionized water from which the samples $5 \mathrm{mg} \mathrm{L}^{-1}$ and $20 \mathrm{mg} \mathrm{L}^{-1}$ in $\mathrm{F}^{-}$for batch adsorption studies were prepared by appropriate dilution. The total ionic strength adjusting buffer (TISAB II) was prepared by dissolving $58.5 \mathrm{~g}$ of sodium chloride, $57 \mathrm{~mL}$ of glacial acetic acid, $7 \mathrm{~g}$ of trisodium citrate, and $2 \mathrm{~g}$ CDTA (cyclohexanediamine tetraacetic acid) in $500 \mathrm{~mL}$ round-bottom flask. The $\mathrm{pH}$ was adjusted to 5.2-5.4 with a solution of $5 \mathrm{M} \mathrm{NaOH}$, which then, diluted to 1000 $\mathrm{mL}$ in a volumetric flask with deionized water following a recommended procedure [22].

\section{Batch adsorption studies}

The adsorption was studied by varying the adsorbent dose from $20 \mathrm{mg} \mathrm{L}^{-1}$ to $100 \mathrm{mg} \mathrm{L}^{-1}(20,60$ and 100) and the initial fluoride concentration of $5 \mathrm{mg} \mathrm{L}^{-1}$ and $20 \mathrm{mg} \mathrm{L}^{-1}$. The desired weight of the adsorbent was added to the desired fluoride solution in a plastic bottle and then stirred thoroughly at room temperature. After continuous stirring in a magnetic stirrer for 20 hours, the samples were filtered. After filtration, a total ionic strength adjusting buffer (TISAB II) was added to the filtrate in 1:1 ratio in order to maintain ionic strength and the $\mathrm{pH}$, and eliminate the interference effect of complexing ions. Finally the equilibrium fluoride concentration was determined. The retention percentage and defluoridation capacity were calculated as follows:

$$
\begin{aligned}
& \text { Retention percentage }(\%)=\frac{\left[\mathrm{F}^{-}\right]_{\mathrm{i}}-\left[\mathrm{F}^{-}\right]_{\mathrm{f}}}{\left[\mathrm{F}^{-}\right]_{\mathrm{i}}} \times 100 \\
& \text { Defluoridation capacity (DC) }=\frac{\left[\mathrm{F}^{-}\right]_{\mathrm{i}}-\left[\mathrm{F}^{-}\right]_{\mathrm{f}}}{\text { Adsorbent Dose }}
\end{aligned}
$$

where, $[\mathrm{F}]_{\mathrm{i}}=$ initial fluoride concentration and $[\mathrm{F}]_{\mathrm{i}}=$ final fluoride concentration.

\section{Determination of $F$ concentration}

A pH/ISE meter (CRISON GLP $2^{2}$, China) equipped with combination fluoride-selective electrode (CRISON Code 96 55) was employed for the determination of $\mathrm{F}^{-}$. The $\mathrm{pH}$ was measured with a $\mathrm{pH} /$ ion meter (CRISON GLP $2^{2}$ ) using an unfilled $\mathrm{pH}$ glass electrode. The residual fluoride concentration was measured according to the procedure described in the instrument manual. The electrode was calibrated prior to each experiment over a concentration range of interest. All measurements were made at room temperature $\left(23 \pm 2{ }^{\circ} \mathrm{C}\right)$. 


\section{Characterization of the zeolites}

Powder X-ray diffraction (XRD) patterns were collected with X'Pert Pro PANalytical. Thermogravimetric analyses (TGA) were performed on Thermogravimetric Analyzer PERKIN ELMER TGA7. Samples were heated at a rate of $20^{\circ} \mathrm{C} \mathrm{min}^{-1}$ to a maximum temperature of 900 ${ }^{\circ} \mathrm{C}$ in a flowing atmosphere of oxygen.

\section{RESULTS}

\section{Characterization of the zeolites}

The features of the zeolites as reported in the bibliography are compared in Table 1. Note how different the channel dimensions and the free pore volumes are. The structural identification of the zeolites from Ethiopia and Mexico was carried out by X-ray diffraction, and the results are compared in Table 2. The samples are rather pure; the only other compounds were quartz and montmorillonite, which are not dangerous for human health.

Table 1. Categorization and structural properties of clinoptilolite, heulandite, stilbite, and analcime taken from the Atlas of Natural Zeolite Framework [23].

\begin{tabular}{|c|c|c|c|c|}
\hline Zeolite & Primary cell formula, structure crystal system & $\begin{array}{c}\text { Channel } \\
\text { dimensions } \\
(\mathrm{nm})\end{array}$ & $\begin{array}{c}\text { Free } \\
\text { volume }\end{array}$ & Exchangeable cations \\
\hline Heulandite & $\left(\mathrm{NaCa}_{0.5} \mathrm{Sr}_{0.5} \mathrm{Ba}_{0.5} \mathrm{Mg}_{0.5} \mathrm{~K}\right)_{9}\left[\mathrm{Al}_{9} \mathrm{Si}_{27} \mathrm{O}_{72}\right] \cdot 24 \mathrm{H}_{2} \mathrm{O}$ & $0.44 \times 0.72$ & 0.39 & $\mathrm{Na}, \mathrm{K}, \mathrm{Ca}, \mathrm{Sr}, \mathrm{Ba}$ \\
\hline Clinoptilolite & $\left(\mathrm{NaKCa}_{0.5} \mathrm{Sr}_{0.5} \mathrm{Ba}_{0.5} \mathrm{Mg}_{0.5}\right)_{6}\left[\mathrm{Al}_{6} \mathrm{Si}_{30} \mathrm{O}_{72}\right] \cdot 20 \mathrm{H}_{2} \mathrm{O}$ & $0.44 \times 0.72$ & 0.34 & $\mathrm{Na}, \mathrm{K}, \mathrm{Ca}, \mathrm{Sr}, \mathrm{Ba}, \mathrm{Mg}$ \\
\hline Stilbite & 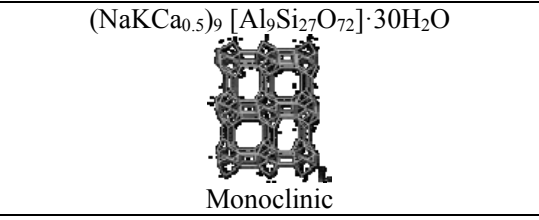 & $0.54 \times 0.69$ & 0.341 & Na. K, Ca, Mg \\
\hline Analcime & Cubic & $0.16 \times 0.42$ & 0.18 & $\mathrm{Na}, \mathrm{K}, \mathrm{Ca}, \mathrm{Rb}, \mathrm{Cs}$ \\
\hline
\end{tabular}

As expected with this characterization technique it is not possible to distinguish between clinoptilolite and heulandite $[24,25]$. Only by complementing XRD studies with temperature based analyses, such information may be obtained. Still, all samples presented, in XRD revealed the expected composition.

Heulandites and clinoptilolite have been distinguished on the basis of their cation contents and $\mathrm{Si} / \mathrm{A} 1$ ratios, with clinoptilolite having $(\mathrm{Na}$ and $\mathrm{K})>\mathrm{Ca}$ and $\mathrm{Si} / \mathrm{A} 1>4$, and heulandite 
having $\mathrm{Ca}>(\mathrm{Na}$ and $\mathrm{K})$ and $\mathrm{Si} / \mathrm{A} 1<4$ [25]. A major difference between the two zeolites is that heulandite undergoes a sluggish phase transition at about $230{ }^{\circ} \mathrm{C}$, whereas clinoptilolite does not [24]. Clinoptilolite is more stable towards dehydration than heulandite. If heulandites are slowly heated, part of their water is lost rapidly at first and then slowly up to $200{ }^{\circ} \mathrm{C}$, at this temperature the mineral again begins to dehydrate very rapidly.

Table 2. Compounds present in the natural zeolites from Ethiopia and Mexico.

\begin{tabular}{|c|c|c|}
\hline Sample & Main compound & Minor compounds \\
\hline Zeocat ECO (Mexico) & Clinoptilolite-Heulandite & --- \\
\hline San Luis Potosí (Mexico) & Clinoptilolite-Heulandite & Quartz, Montmorillonite \\
\hline Puebla (Mexico) & Clinoptilolite-Heulandite & Amorphous \\
\hline Hashenge (Ethiopia) & Stilbite & --- \\
\hline Tigray (Ethiopia) & Analcime & $\begin{array}{c}\text { Vermiculite, small fraction of } \\
\text { non-crystalline material }\end{array}$ \\
\hline
\end{tabular}

In Figure 3, the TGA curves obtained in air atmosphere are shown. The TGA curves show that the zeolites from San Luis Potosí (Mexico) and Zeocat ECO (Mexico) have higher stability towards dehydration than the zeolite collected in Puebla (Mexico). Therefore, the zeolites San Luis Potosí and Zeocat ECO are clinoptilolite, but the Puebla zeolite is heulandite, bearing in mind that $\mathrm{Si} / \mathrm{Al}$ ratio is higher in clinoptilolite.

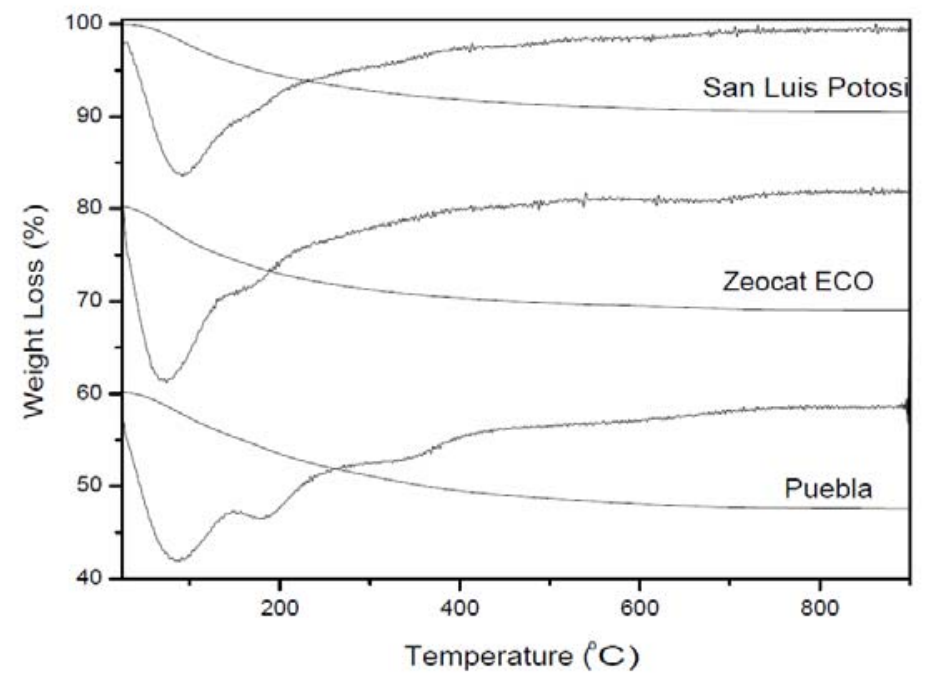

Figure 3. Thermogravimetric analyses of Mexican natural zeolites.

\section{Fluoride retention studies}

The fluoride retention of each sample is summarized and compared in Tables 3 and 4 for two different initial $\mathrm{F}^{-}$concentration. The first one corresponds to an initial fluoride concentration of $20 \mathrm{mg} \mathrm{L}^{-1}$, and the second to $5 \mathrm{mg} \mathrm{L}^{-1}$. In all cases, the fluoride retention percentage increases with the increasing adsorbent dose and the initial fluoride concentration, for all compared zeolites. If the initial fluoride concentration is $20 \mathrm{mg} \mathrm{L}^{-1}$, the performance of the clinoptilolite samples (San Luis Potosí and Zeocat ECO) reaches 10\% and around 20\% of fluoride retention 
for low $\left(20 \mathrm{mg} \mathrm{L}^{-1}\right)$ and high $\left(100 \mathrm{mg} \mathrm{L}^{-1}\right)$ adsorbent doses. These values are ca. $10 \%$ higher than the values obtained for stilbite and heulandite but between three and four times lower than the fluoride retention of analcime. If the initial fluoride concentration is $5 \mathrm{mg} \mathrm{L}^{-1}$, the performance of the clinoptilolite sample from San Luis Potosí only reaches $15 \%$ of fluoride retention for high $\left(100 \mathrm{mg} \mathrm{L}^{-1}\right)$ adsorbent doses. Instead, the analcime from Ethiopia retains more than $83 \%$, i.e. more than 5.5 times.

Table 3. Fluoride retention percentage as a function of adsorbent dose. The initial fluoride concentration was $20 \mathrm{mg} \mathrm{L}^{-1}$.

\begin{tabular}{|c|c|c|c|c|c|}
\hline \multirow{2}{*}{$\begin{array}{c}\text { Adsorbent dose } \\
(\mathrm{g} / \mathrm{L})\end{array}$} & \multicolumn{5}{|c|}{ Fluoride retention (\%) } \\
\cline { 2 - 6 } & Zeocat ECO & San Luis Potosi & Puebla & Stilbite & Analcime \\
\hline 20 & 10.2 & 10.4 & - & - & 23.5 \\
\hline 60 & 16.5 & 14.6 & 12.4 & 12.1 & 56.3 \\
\hline 100 & 22.1 & 20.4 & 19.6 & 21.9 & 76.5 \\
\hline
\end{tabular}

Table 4. Fluoride retention percentage as a function of adsorbent dose using an initial fluoride concentration of $5 \mathrm{mg} \mathrm{L}^{-1}$.

\begin{tabular}{|c|c|c|c|}
\hline $\begin{array}{c}\text { Adsorbent dose } \\
(\mathrm{g} / \mathrm{L})\end{array}$ & Zeocat ECO & San Luis Potosi & Analcime \\
\cline { 2 - 4 } & 0.4 & 2 & 32 \\
\hline 20 & 3.8 & 5.6 & 76 \\
\hline 60 & 5.6 & 16.2 & 84 \\
\hline 100 & \multicolumn{3}{|c|}{} \\
\hline
\end{tabular}

\section{DISCUSSION}

Three natural zeolites from Mexico were tested for fluoride removal and the results are compared with the performance of two zeolites from Ethiopia. The zeolites differ in their structure, their $\mathrm{Si} / \mathrm{Al}$ ratio, and their exchangeable cations among other parameters. However, some clear trends can be established. In all cases the best zeolite to retain fluoride, among the five studied in this work, is analcime. This zeolite presents the smallest channel dimensions and the lowest free pore volume. Therefore, at this level, any mechanism based on diffusion has to be rejected. Indeed, fluoride is a very small ion (ionic radius $0.136 \mathrm{~nm}$ ) and it is expected to move easily into clinoptilolite, heulandite, or stilbite networks; in analcime it cannot enter. The rather good retention of analcime is attributed to extraframework aluminum compounds (alumina or aluminum hydroxide) and to connectivity defects. Such hypothesis is in agreement with NMR results which showed the presence of octahedral aluminum atoms [19]. Of course, such aluminum compounds have to be located outside the analcime crystallites. The analcime crystals, being natural, must present cracks, crystallization defects, and some mesoporosity able to host the aluminum compound nanoparticles. Then, the crystallites of analcime maintain their composition, i.e. no cationic exchange with fluoride or any other cation will take place.

On the other hand, if the clinoptilolites of this study do not retain as much fluoride, it must be due to the absence of octahedral aluminum atoms. However, they do retain some fluoride, and furthermore, the amount is higher than in stilbite or heulandite. Clinoptilolite is known to have a $\mathrm{Si} / \mathrm{Al}$ ratio higher than 4 whereas heulandite corresponds to $\mathrm{Si} / \mathrm{Al}$ ratio lower than 4 [23]. Then, as clinoptilolite has less aluminum atoms, it is less negatively charged and should offer less resistance to fluoride acceptance. But, clinoptilolite exchangeable cations are $\mathrm{Na}$ and $\mathrm{K}$ which exceed those of $\mathrm{Ca}$, instead heulandite has also $\mathrm{Na}$ as well as $\mathrm{K}$ cations which are less than those of $\mathrm{Ca}$. Highly charged cations as $\mathrm{Ca}$ are efficient sites for fluoride retention. Therefore, the difference between the performance of those zeolites cannot be assigned to their 
slight structural differences but to the amount of amorphous compound present in the heulandite from Puebla which most probably partially blocks the pore entrances.

However, the above discussion is not valid for stilbite whose $\mathrm{Si} / \mathrm{Al}$ ratio is 2.7 and whose free pore volume is the same as the free pore volume of clinoptilolite. To explain the differences in fluoride retention we have mentioned first the presence of extraframework aluminum, then the importance of $\mathrm{Si} / \mathrm{Al}$ ratio; but, we have not taken into account the type of exchangeable cation into the zeolite network. Zeolites are cation exchangers and are not prone to retain anions. Still the charge balance into the zeolite network may be reversed or at least altered introducing into the cavities and channels highly charged cations. For instance, silver exchanged zeolites have been reported to retain efficiently iodine anions. Silver zeolite cartridges are typically used in nuclear power plants to adsorb gaseous iodine [26]. The introduction of sulfur into zeolite networks modifies remarkably the charge equilibrium into the zeolite lattice [27]. It is not surprising, then, that if the cations of stilbite are fully exchanged to calcium, the performance of the sample in fluoride retention is increased not only because connectivity defects are generated during the exchange treatments [21], but because the calcium ions are divalent and highly charged; and, thus, the performance of stilbite previously mentionned as not depending on $\mathrm{Si} / \mathrm{Al}$ ratio may be explained. If stilbite contains exchangeable cations, which only balance the charge network and do not create zones highly charged, fluoride is not retained.

Therefore, in this work, two mechanisms of fluoride retention in zeolites are proposed. On the one hand, fluoride retention may be attributed to a high number of connectivity defects and to a high amount of detrital aluminum compounds present in some zeolites, as already proposed by Gómez-Hortigüela et al. in a previous work [19]. This mechanism is independent of the type of zeolite structure. In this scenario, fluoride substitutes $\mathrm{OH}$ radicals and it is strongly retained. On the other hand, fluoride retention may be attributed to a typical adsorption force generated around some highly charged cations, for instance, calcium. Of course, the amount of exchangeable cations, proportional to the $\mathrm{Si} / \mathrm{Al}$ ratio, is crucial. This adsorption bond is weak and fluorine is expected to leach easily.

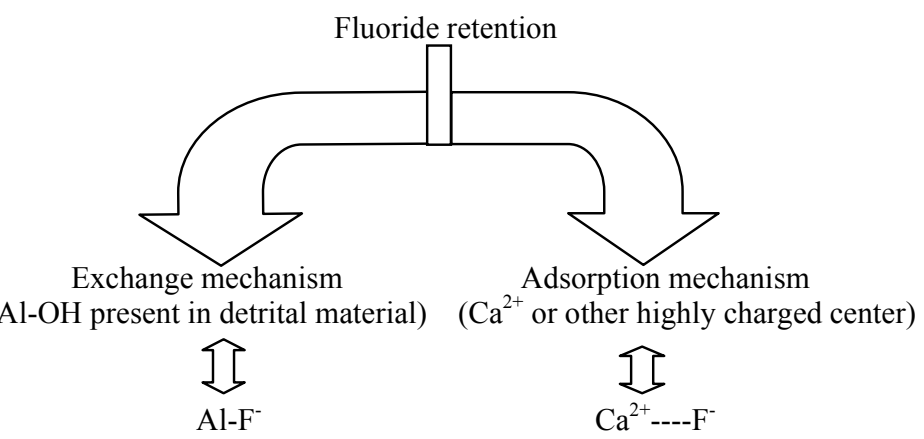

Figure 4. Suggested mechanisms for fluoride retention in natural zeolites.

These two propositions are not exclusive, most probably in some zeolites containing calcium, or any other divalent cation, on a first step some fluoride is adsorbed in the vicinity of the calcium atoms and, then, the remaining fluoride, in a second step, or simultaneously, is exchanged with the $\mathrm{OH}$ radicals of the detrital material. Both mechanisms are schematized in Figure 4. 


\section{CONCLUSION}

Two types of fluoride retention mechanisms are proposed. One mechanism could be that, as the ionic radius of the fluoride ion $(0.136 \mathrm{~nm})$ is similar to that of the hydroxyl ion $(0.140 \mathrm{~nm})$, fluoride is exchanged in detrital materials or in connectivity defects of the zeolite. The bond must be strong. The second mechanism is that, despite the fact that zeolites are cationexchangers, anions may interact with highly charged cations. Fluoride anion may be, therefore, occluded in zeolite cavities. The bond must be weak.

Analcime retained up to $85 \%$ of the fluoride present in a solution whose initial fluoride concentration was $5 \mathrm{mg} \mathrm{L}^{-1}$ for an adsorbent dose of $100 \mathrm{mg} \mathrm{L}^{-1}$. Such high amount is attributed to the extra-framework compounds, mainly obeying the first suggested mechanism. The other zeolites, under the same conditions, following the second mechanism, only capture $c a$. 5 to $15 \%$ of fluoride. Therefore, the defluoridation capacity of zeolites should be improved promoting the formation of defects and extraframework compounds in the zeolite networks, independently of the zeolite type.

\section{ACKNOWLEDGEMENTS}

Zeocat and J. Krason are acknowledged for the kind donation of Zeocat ECO and San Luis Potosi zeolites, respectively. PB deeply appreciates Universidad Autonoma Nacional de Mexico for supporting him on his sabbatical leave at AAU. ID is grateful to CSIC for her research leave at AAU. The financial support from the Spanish Government MINECO (project MAT201231127) and the Spanish Research Council CSIC I-COOP- $\mathrm{H}_{2} \mathrm{O}$ (project 2013CD0009) is acknowledged. The Chemistry Department, Addis Ababa University is also acknowledged for financial support (TR/008/2011).

\section{REFERENCES}

1. Mahramanlioglu, M.; Kizilcikli, I.; Bicer, I.O. J. Fluorine Chem. 2002, 115, 41.

2. Harrison, P.T.C. J. Fluorine Chem. 2005, 126, 1448.

3. Paulson, E.G. Chem. Eng. 1977, 84, 89.

4. World Health Organization, Guidelines for Drinking Water Quality, WHO: Geneva, Switzerland; 1993.

5. The World Health Organization, Guidelines for Drinking-Water Quality, Volume 1: Recommendations and Volume 2: Health Criteria and Other Supporting Information, WHO: Geneva, Switzerland; 1984.

6. UNICEF's Position on Water Fluoridation. Available at: http://www.nofluoride.com/Unicef_fluor.cfm consulted on march 31, 2014.

7. Kloos, H.; Haimanot. R.T. Trop. Med. Int. Health. 1999, 4, 355.

8. Tekle-Haimanot, R.; Fekadu, A.; Bushera, B.; Mekonnen, Y. Fluoride levels in water and endemic fluorosis in Ethiopian Rift valley, $1^{\text {st }}$ International Workshop on Fluorosis Prevention and Defluoridation of Water. Int. Soc. Fluoride Res., Dahi, E.; Bregnhoj, H. (Eds.), Ngurdoto, Tanzania, October 18-22, 1995; p 12.

9. Haimanot, R.T.; Fekadu, A.; Bushra, B. Trop. Geogr. Med. 1987, 39, 209.

10. Díaz-Barriga, F.; Navarro-Quezada, A.; Grijalva, M. I.; Grimaldo, M.; Loyola-Rodríguez, J. P.; Deogracias-Ortiz, M. Fluoride 1997, 30, 233.

11. Galicia Chacón, L.; Molina Frechero, N.; Oropeza Oropeza, A.; Gaona, E.; Juárez López, L. Rev. Int. Contam. Ambie. 2011, 27, 283.

12. Mullen. J. Brit. Dent. J. 2005, 199, 1.

13. Jagtap, S.; Yenkie, M.K.; Labhsetwar, N.; Rayalu, S. Chem. Rev. 2012, 112, 2454.

14. Ku, Y.; Chiou, H.M. Water Air Soil Pollut. 2002, 133, 349.

15. Leyva Ramos, R.; Ovalle-Turrubiartes, J.; Sánchez-Castillo, M.A. Carbon. 1999, 37, 609. 
16. Ogata, F.; Tominaga, H.; Yabutani, H.; Kawasaki, N. J. Oleo. Sc. 2011, 60, 619.

17. Breck, D. W. Zeolite Molecular Sieves, John Wiley and Sons: New York; 1974.

18. Bosch, P.; Olguin, M.T.; Bulbulian, S. Zeolitas Naturales, Características Propiedades Y Usos, Universidad Nacional Autónoma de México: México D.F.; 2011.

19. Gómez-Hortigüela, L.; Pérez-Pariente, J.; García, R.; Chebude, Y.; Díaz, I. Sep. Pur. Technol. 2013, 120, 224.

20. Díaz-Nava, C.; Olguín, M.T.; Solache-Ríos, M. Sep. Sci. Technol. 2002, 37, 3109.

21. Gómez-Hortigüela, L.; Pinar, A.B.; Pérez-Pariente, J.; Sani, T.; Chebude, Y.; Díaz, I. Micropor. Mesopor. Mater. 2014, 193, 93.

22. Dessalegne, M.; Zewge, F. Toxicol. Environ. Chem. 2013, 95, 1056.

23. Wise, W.S.; Colella, C. (Eds.) Handbook of Natural Zeolites Naples: De Frede Editore; 2013.

24. Mumpton, F.A. Amer. Mineral. 1960, 45, 351.

25. Boles, J.R. Amer. Mineral. 1972, 57, 1463.

26. Wang, W.H.; Matthews, K.L. Health Phys. 2006, 90, S73.

27. Loera Serna, S. Retención de Gases en Zeolitas. Doctorado en Ciencia e Ingeniería de Materiales, Instituto de Investigaciones en Materiales: U.N.A.M.; 29 de Septiembre de 2010. 